\title{
Trachiyspirum ammi (L.) Sprague ex Turrill Seed Extracts Lack Antibacterial Activity
}

\author{
Muhammad Jawad Yousaf Zai ${ }^{1}$, Ian Edwin Cock $^{1,2^{*}}$ \\ 1School of Environment and Science, Nathan Campus, Griffith University, 170 Kessels Rd, Nathan, Brisbane, Queensland, AUSTRALIA. \\ 2Environmental Futures Research Institute, Griffith University, 170 Kessels Rd, Nathan, Brisbane, Queensland, AUSTRALIA.
}

\begin{abstract}
Introduction: Trachyspermum ammi leaves and seeds have been used as dietary supplements and to treat multiple pathogenic diseases in several traditional healing systems. Despite this, their therapeutic properties have been poorly studied. Methods: Chloroform, ethyl acetate, hexane, methanol and water extracts of $T$. ammi were prepared and tested and the activity was compared to that of standard antibiotics for their in vitro antibacterial activity against ten human bacterial pathogens. The antibacterial activity was studied by standard disc diffusion assays and the activity was recorded as zones of inhibition. Results: All T. ammi seed extracts were ineffective at inhibiting the growth of all of the gram-positive and gram-negative bacteria pathogens screened against. Conclusion: Despite their use in traditional healing systems to treat some pathogenic diseases, T. ammi seed extracts were completely ineffective bacterial growth inhibitors. However, these
\end{abstract}

extracts were screened against a limited panel of bacteria and further testing against other pathogens is required.

Key words: Ajwain, Bishops weed, Apiaceae, Antibacterial activity, Traditional medicine, Medicinal plants.

\section{Correspondence:}

Dr. Ian Edwin Cock

'School of Environment and Science, Nathan Campus, Griffith University, 170 Kessels Rd, Nathan, Brisbane, Queensland-4111, AUSTRALIA.

${ }^{2}$ Environmental Futures Research Institute, Griffith University, 170 Kessels Rd, Nathan, Brisbane, Queensland-4111, AUSTRALIA

Phone no: +61737357637

E-mail: I.Cock@griffith.edu.au

DOI: $10.5530 /$ pc.2020.3.27

\section{INTRODUCTION}

Traditional plant derived medicines are used by multiple ethnic groups globally for a variety of therapeutic purposes, including for the treatment of diseases caused by microbial pathogens. Interestingly, the potential of plant extracts to inhibit the growth of pathogenic bacteria has gained considerable momentum in recent studies. ${ }^{1-5}$ Most studies have focused on African, ${ }^{6-8}$ Asian, ${ }^{9-11}$ South American ${ }^{12}$ and Middle Eastern plants. ${ }^{5,13,14}$ Despite this, the capability of traditional plants to offer useful pharmaceutical benefits remains poorly explored. Approximately 5-10\% of the 300,000-500,000 plant species across the world have been studied for therapeutic bioactivities. ${ }^{9}$ With plenty of plant species yet to be screened, it is paramount that plant selection processes narrow down the field to highlight the species with higher likelihood of providing viable new drug leads. One of the main selection criteria is to select plants which have documented uses as traditional medicines based upon their ethnobotanical usage. Another important selection criteria is based upon examining plants for which medicinal capacity is well established, or on species taxonomically related to species used traditionally. The investigation of traditional medicinal plants may lead to the discoveries of natural therapies.

The recent evolution of bacterial pathogens to strains that are either totally or extremely resistant to conventional antibiotics ${ }^{15}$ has rendered many clinical antibiotics of substantially lower efficacy, or in some cases has rendered them completely ineffective. There is now an urgent need to look for new and more effective antibiotic therapies. There are currently limited therapeutic options available for many diseases that are caused by resistant bacterial pathogens and the situation is expected to worsen in the future as the bacteria exchange resistance genes, rendering further pathogens resistant to clinical antibiotics. According to World Health Organization (WHO) the development of new antibiotic therapies is one of the most serious challenges currently faced by the medical community. Traditional medicines have a great capacity for the development of new antimicrobial drugs, explaining the considerable recent increase in interest in this discipline. ${ }^{16,17}$
Trachiyspirum ammi (L.) Sprague ex Turrill (commonly known as ajwain, bishops weed or carom) (Figure 1) is an annual herb that is native to Egypt and is widely cultivated in Afghanistan, Iran, Iraq, India and Pakistan. T. ammi belongs to family Apiaceae and is a highly valued medicinal seed. Analysis of ajwain seeds revealed that it contains fiber (11.9\%), tannins, glycosides, carbohydrates (38.6\%), moisture (8.9\%), fat $(18.1 \%)$, protein $(15.4 \%)$, flavone, saponins and mineral matter $(7.1 \%)$ containing phosphorus, calcium, iron and nicotinic acid. ${ }^{18}$ The seed contains around $2-4.4 \%$ of brown colored oil called ajwain oil and the primary component of this oil is thymol, which is widely used in the treatment of gastrointestinal diseases. ${ }^{19}$ The non-thymolic fraction contains $\gamma$-terpenine, dipentene, $\alpha$ - and $\beta$-pinenes, carvacrol and $\alpha$-terpinene. ${ }^{20}$ It is widely grown in areas where soil contains more salts. ${ }^{21,22}$ T. ammi is a $60-90 \mathrm{~cm}$ tall branched annual herb. Due to the therapeutic and commercial importance of T. ammi, this study was designed to screen T. ammi seed extracts for the ability to restrict the growth of a panel of gastrointestinal and autoimmune bacterial pathogens.

\section{MATERIALS AND METHODS}

\section{Plant material and extraction}

T. ammi seeds were purchased from Noodles Emporium, Australia (an online herbalist) and were originally sourced from Egypt. A voucher sample (GU-TANE19a) is stored in the School of Environment and Science, Griffith University, Australia. Individual $1 \mathrm{~g}$ masses of the seed were extracted individually in five different tubes each containing $50 \mathrm{~mL}$ of methanol, deionized water, ethyl acetate, chloroform or hexane overnight at room temperature. The extract was then filtered through the Whatman number 1 filter paper and subsequently dried at $60^{\circ} \mathrm{C}$ under vacuum. The resultant pellet was weighed to determine extraction yield and dissolved in $100 \mu \mathrm{L}$ of dimethyl sulfoxide (DMSO). The volume was then increased to $10 \mathrm{~mL}$ with the addition of deionized water. The extract was filtered through $0.22 \mu \mathrm{m}$ filter (Millipore) to remove microbial contaminants and stored at the room temperature until use. 


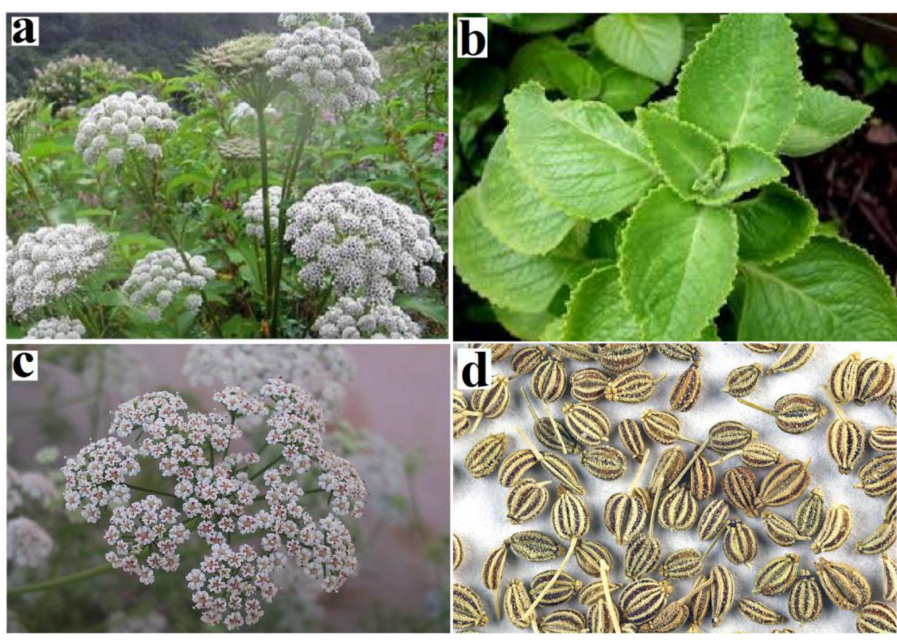

Figure 1: Trachiyspirum ammi (a) whole plant, (b) leaves, (c), flowers and (d) seeds.

\section{Antibacterial screening Test microorganisms}

Clinical isolate microbial strains of gram-negative bacteria (Escherichia coli, Shigella sonneii, Aeromonas hydrophilia, Salmonella newport, Proteus mirabilis, Klebsiella pneumonia, Acinetobacter baylyi, Pseudomonas aeruginosa and gram-positive bacteria (Bacillus cereus, Enterococcus faecalis, Streptococcus pyogene) were obtained from Ms. Michelle Mendell and Ms. Jane Gifkins, Griffith University. All the bacterial stock culture was sub-cultured and grown to $\log$ phase at $37^{\circ} \mathrm{C}$. The cultures were maintained in nutrient broth (Oxoid, Australia) at $4^{\circ} \mathrm{C}$ until use.

\section{Evaluation of antimicrobial activity}

Antimicrobial activity of the T. ammi seed extracts was determined using a disc diffusion assay. ${ }^{23}$ Briefly, $100 \mu \mathrm{L}$ of each of the microbial suspension in the log phase was spread onto individual nutrient agar plates. The extracts were screened for antimicrobial activity using $6 \mathrm{~mm}$ sterilized filter paper discs. Each disc was infused with $10 \mu \mathrm{L}$ of the individual seed extracts and allowed to dry before incubated at $37^{\circ} \mathrm{C}$ for $24 \mathrm{~h}$. The diameter of the zone of inhibition (ZOIs) were measured to the closest possible whole millimeters. Each assay was performed in triplicate $(n=3)$. Mean values $( \pm$ SEM) are reported in the study. Standard discs of tetracycline $(10 \mu \mathrm{g})$ and ampicillin $(2 \mu \mathrm{g})$ were used as a positive control to compare antibacterial activity. Filter disc infused with the $10 \mu \mathrm{L}$ of deionized water were included on each plate as negative controls.

\section{Statistical analysis}

Data is expressed as the mean \pm SEM of two independent experiments, each with internal triplicates $(n=6)$. One-way ANOVA is used to calculate the statistical between the control and treated groups, with a $P$ value $<0.01$ is consider to be statistically significant.

\section{RESULTS}

\section{Liquid extraction yields}

The extracted yield of $1 \mathrm{~g}$ of dried seeds in methanol, water, ethyl acetate, chloroform and hexane is shown in the Table 1 . The extracts were re-suspended in $10 \mathrm{~mL}$ of deionized water (having $1 \% \mathrm{DMSO}$ ), resulting in the extract concentration shown in Table 1.
Table 1: The mass of dried extracted material and the concentration after resuspension in deionized water.

\begin{tabular}{ccc}
\hline & $\begin{array}{c}\text { Mass of extracted } \\
\text { material }(\mathrm{mg})\end{array}$ & $\begin{array}{c}\text { Concentration of } \\
\text { re-suspended extract }(\mathrm{mg} / \mathrm{ml})\end{array}$ \\
\hline Methanol & 31.5 & 3.15 \\
Water & 144 & 14.4 \\
Ethyl acetate & 1.5 & 0.15 \\
Chloroform & 9 & 0.9 \\
Hexane & 12.55 & 1.25 \\
\hline
\end{tabular}
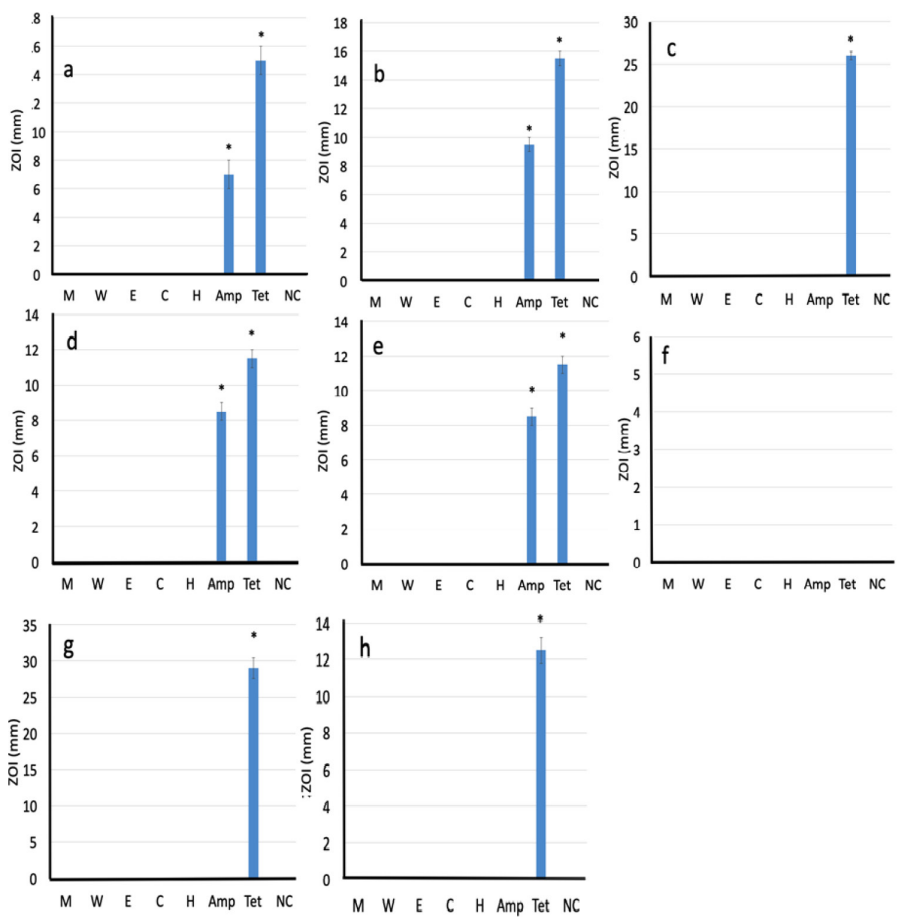

Figure 2: Growth inhibitory activity of T. ammi seed extracts and reference antibiotics against gram-negative bacterial species $(\mathrm{a}=E$. coli, $\mathrm{b}=\mathrm{S}$. sonnei, $\mathrm{c}=$ A. hydrophilia, $\mathrm{d}=\mathrm{S}$. newport, $\mathrm{e}=P$. mirablis, $\mathrm{f}=$ K. pneumonia, $\mathrm{g}=$ A. baylyi, $\mathrm{h}=P$. aeruginosa) measured as ZOls $(\mathrm{mm}) \pm \mathrm{SEM} . \mathrm{M}=$ methanol, $\mathrm{W}=$ water, $\mathrm{E}=$ ethyl acetate, $\mathrm{C}=$ chloroform, $\mathrm{H}=$ hexane, $\mathrm{A}=$ ampicillin $(2 \mu \mathrm{g})$;

$\mathrm{T}=$ tetracycline $(10 \mu \mathrm{g}) ; \mathrm{NC}=$ negative control. All assays were completed twice, each with internal triplicates $(n=6)$ and the results are expressed as mean zones of inhibition $(\mathrm{mm}) \pm \mathrm{SEM}$.

\section{Antimicrobial activity}

In order to determine the growth inhibitory activity of the T. ammi seeds extract, $10 \mu \mathrm{L}$ aliquots of each extract were screened in the disc diffusion assay. The T. ammi seeds extract were ineffective at inhibiting the growth of all gram-negative (Figure 2) and gram-positive (Figure 3) tested bacterial species. On the other hand, both the positive control antibiotics (ampicillin and tetracycline) were effective growth inhibitors except the K. pneumonia which is totally resistant against both ampicillin and tetracycline. The zone of inhibition of up to $17 \mathrm{~mm}$ is recorded for tetracycline against E. coli. Ampicillin is found to be resistant against A. hydrophilia, A. baylyi and P. aeruginosa. Similarly, B. cereus and $S$. pyogene were resistant to ampicillin, against whilst $E$. faecalis showed some activity against ampicillin. 

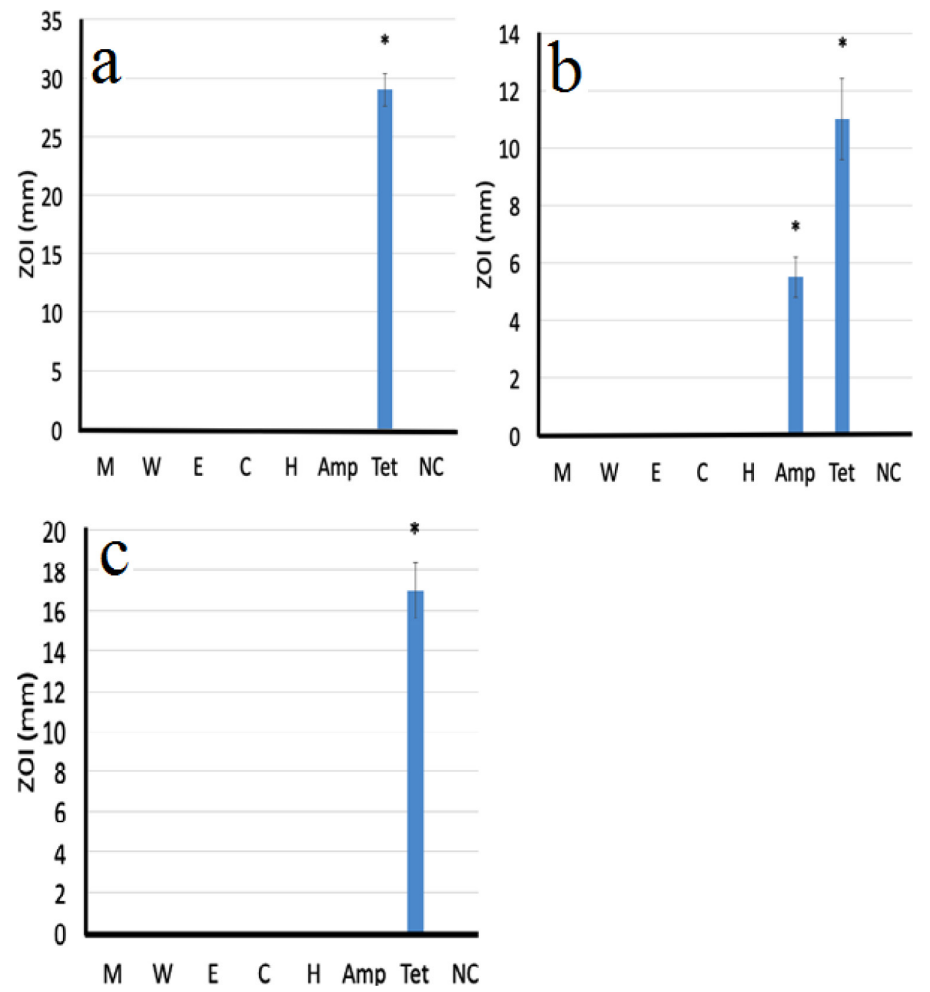

Figure 3: Growth inhibitory activity of T. ammi seed extracts and reference antibiotics against gram-positive bacterial species $(a=B$. cereus, $b=E$. faecalis, $\mathrm{c}=\mathrm{S}$. pyogene) measured as ZOIs $(\mathrm{mm}) \pm \mathrm{SEM} . \mathrm{M}=$ methanol, $\mathrm{W}=$ water, $\mathrm{E}=$ ethyl acetate, $\mathrm{C}=$ cholrofrom, $\mathrm{H}=$ hexane, $\mathrm{A}=$ ampicillin $(2 \mu \mathrm{g}) ; \mathrm{T}=$ tetracycline $(10 \mu g) ; \mathrm{NC}=$ negative control. All assays were completed twice, each with internal triplicates $(n=6)$ and the results are expressed as mean zones of inhibition $(\mathrm{mm}) \pm$ SEM.

\section{DISCUSSION}

Due to the continuous evolution in bacterial resistance to many antibiotics, the development of new antibiotic therapies is the utmost priority of medical science. ${ }^{15,22}$ A simultaneous decline in the discovery of new antibiotics by traditional ways has raised interest in re-examining medicinal plants for new antibiotic therapies. ${ }^{24} \mathrm{~T}$. ammi belongs to the family of Apiaceae and is a highly valued medicinally important seed. The Apiaceae plant family includes celery, carrot and parsley. A common feature of these species is that they contain a group of bioactive aliphatic $\mathrm{C}_{17}$ called polyacetylenes. Polyacetylenes possess potent antimicrobial effects against panels of bacteria, fungi, mammalian cells. $^{25}$ They also display anti-inflammatory, anti-platelet-aggregatory and neurotoxic effects. ${ }^{25}$ T. ammi also possesses hypolipidemic, ${ }^{26}$ antimicrobial, ${ }^{27}$ antihypertensive, antispasmodic, hepatoprotective, bronchodilating ${ }^{28}$ and digestive effects. ${ }^{29}$

A single assay technique was used to screen for the antibacterial activity in this study. Disc diffusion assays were used in this study as it is a rapid method and has been widely used in other studies. The disc diffusion assay relies on the diffusion of molecule through the aqueous environment of an agar gel, this procedure may be affected by the solubility of the extract compounds in aqueous environment. Chloroform, ethyl acetate, hexane, methanol and water extracts of T. ammi were used in the disc diffusion assays in this study. Notably, the lower polarity extracts would contain lower polarity compounds which may be unable to diffuse readily through the agar gel. Therefore, false negatives may have been obtained against those extracts. Other methods, including liquid dilution assays may have provided a more accurate measurement of the antibacterial activity of those extracts and such studies are planned in the future. Furthermore, liquid dilution assays are generally considered to be more sensitive that solid phase inhibition assays.

Notably, our study tested against a limited panel of bacterial pathogens. It is possible that inhibitory activity may have been detected if the extracts were tested against an extended panel of bacteria. Furthermore, the literature on the traditional uses of this species as a medicine is incomplete. The species is listed as useful in the treatment of several pathogenic diseases, yet the specific uses are not stated. As gastrointestinal and autoimmune diseases can be caused by multiple pathogen types, these extracts may have inhibitory properties against fungal, protozoal and viral pathogens, as well as against tumour cells and further testing is required to more completely evaluate the therapeutic potential of T. ammi.

\section{CONCLUSION}

Chloroform, ethyl acetate, hexane, methanol and water extracts of T. ammi displayed no antibacterial activity in the disc diffusion and liquid dilution assays against the panels of human pathogenic bacteria.

\section{ACKNOWLEDGEMENT}

The authors are grateful to Michelle Mendell and Jane Gifkins of Griffith University for providing the clinical bacterial strains screened in this study. Financial support for this work was provided by the Environmental Futures Research Institute and the School of Environment and Science, Griffith University, Australia.

\section{CONFLICT OF INTEREST}

The authors declare no conflicts of interest

\section{ABBREVIATIONS USED}

DMSO: Dimethyl sulfoxide; $\mathbf{L C}_{50}$ : The concentration required to achieve $50 \%$ mortality; MIC: minimum inhibitory concentration; ZOI: zone of inhibition.

\section{SUMMARY}

- T. ammi seed extracts were screened for the ability to block the growth of a panel of human bacterial pathogens.

- No inhibitory activity was evident against any of the bacterial species tested.

- $\quad$ Toxicity of the T. ammi extracts was determined using the Artemia nauplii toxicity bioassay.

- All extracts were non-toxic.

\section{REFERENCES}

1. Kamboj VP. Herbal medicine. Curr Sci. 2000;78(1):35-9

2. Hostettmann K, Hamburger M. Search for new lead compounds of natural origin. In Perspectives in Medical Chemistry. 1993.

3. Wright MH, Sirdaarta J, White A, et al. GC-MS headspace analysis of Terminalia ferdinandiana fruit and leaf extracts which inhibit Bacillus anthracis growth. Pharmacog J. 2017;9(1):73-82. DOI:P 10.5530/pj.2017.1.14

4. Mpala LN, Chikowe GR, Cock IE. Growth inhibitory properties of extracts prepared from selected Leptospermum and Melaleuca species against a panel of pathogenic bacteria. Pharmacog Commn. 2016;6(4):215-24. DOI: 10.5530/ pc.2016.4.4

5. Omer E, Elshamy Al, Nassar M, et al. Plantago squarrosa Murray extracts inhibit the growth of some bacterial triggers of autoimmune diseases: GC-MS analysis of an inhibitory extract. Inflammopharmacol. 2018;1-3. DOI: 10.1007/ s10787-018-0547-0

6. Gilani AH, Atta-ur R. Trends in ethnopharmacology. J Ethnopharmacol. 2005; 100(1-2):43-9.

7. Hübsch Z, ZyI RLV, Cock IE, Vuuren SFV. Interactive antimicrobial and toxicity profiles of conventional antimicrobials with Southern African medicinal plants. 
S Afr J Bot. 2014;93:185-97. DOI: 10.1016/j.sajb.2014.04.005.

8. Cock IE, Vuuren SFV. Anti-Proteus activity of some South African medicinal plants: Their potential for the treatment and prevention of rheumatoid arthritis. Inflammopharmacol. 2014;22(1):23-36. DOI 10.1007/s10787-013-0179-3.

9. Newman DJ, Cragg GM, Snader KM. The influence of natural products on drug discovery. Nat Prod Rep. 2000;17(3):215-34.

10. Gaillot C, Sirdaarta J, Cock IE. Examination of the antimicrobial and anticancer properties of mangosteen. Acta Hortic. 2016;1106:231-8.

11. Wright $\mathrm{MH}$, Greene AC, Cock IE. Investigating the pharmacognostic potential of Indian Terminalia spp. in the treatment and prevention of yersiniosis. Pharmacog Commn. 2017;7(3):108-13. DOI: 10.5530/pc.2017.3.16

12. Mohanty S, Cock IE. Evaluation of the antibacterial activity and toxicity of Myrciaria caulifloria methanolic leaf and fruit extracts. Int J Microbiol. 2009;7(2).

13. Biggs I, Sirdaarta J, White A, Cock IE. GC-MS analysis of Commiphora molmo oleo-resin extracts which inhibit the growth of bacterial triggers of selected autoimmune diseases. Pharmacog J. 2016;8(3):191-202. DOI: 10.5530/ pj.2016.3.4

14. Biggs I, Sirdaarta J, White A, Cock IE. GC-MS analysis of frankincense extracts which inhibit the growth of bacterial triggers of selected autoimmune diseases. Pharmacog Commn. 2016;6(1):10-22. DOI: 10.5530/pc.2016.1.3

15. Cheesman MJ, Ilanko A, Blonk B, Cock IE. Developing new antimicrobial therapies: Are synergistic combinations of plant extracts/compounds with conventional antibiotics the solution?. Pharmacog Rev. 2017:11(2):57-72. DOI: 10.4103/phrev.phrev_21_17

16. llanko A, Cock IE. The interactive antimicrobial activity of conventional antibiotics and Petalostigma spp. Extracts against bacterial triggers of some autoimmune inflammatory diseases. Pharmacog J. 2019;11(2).

17. Sirdaarta J, Matthews B, Cock IE. Kakadu plum fruit extracts inhibit the growth of the bacterial triggers of rheumatoid arthritis: Identification of stilbene and tannin components. J Funct Food. 2015;17:610-20. DOI: 10.1016/j.jff.2015.06.019
18. Pruthi JS. Spices and Condiments. $4^{\text {th }}$ ed. New Delhi: National Book Trust. 1992.

19. Ishikawah T, Sega Y, Kitajima J. Water-soluble constituents of ajowan. Chem Pharm Bull. 2001;49(7):840-4.

20. Chopra RN. Chopra's Indigenous Drug of India. $2^{\text {nd }}$ ed. Calcutta: Academic Publishers. 1982;93-4.

21. Ashraf M. Salt tolerance of cotton, some new advances. Crit Rev Plant Sci. 2002; 2:1-30

22. Munns R. Comparative physiology of salt and water stress. Plant Cell Environ. 2002:25(2):239-50.

23. Cock IE, Vuuren SFV. South African food and medicinal plant extracts as potential antimicrobial food agents. J Food Sci Tech. 2015;52(11):6879-99.

24. Aiyegoro OA, Okoh Al. Use of bioactive plant products in combination with standard antibiotics: Implications in antimicrobial chemotherapy. J Med Plant Res. 2009;3(13):1147-52

25. Christensen LP Brandt K. Bioactive polyacetylenes in food plants of the Apiaceae family: Occurrence, bioactivity and analysis. J Pharmaceut Biomed. 2006;41(3):683-93.

26. Kumari KS, Prameela M. Effect of incorporating Carum copticum seeds in a high fat diet for albino rats. Med Sci Res. 1992;20:219-20.

27. Bonjar GH. Anti-yeast activity of some plants used in traditional herbal-medicine of Iran. J Biol Sci. 2004;4(212):5.

28. Gilani AH, Jabeen $\mathrm{O}$, Ghayur MN, Janbaz KH, Akhtar MS. Studies on the antihypertensive, antispasmodic, bronchodilator and hepatoprotective activities of the Carum copticum seed extract. Journal of Ethnopharmacol. 2005;98(1-2): $127-35$

29. Vasudevan K, Vembar S, Veeraraghavan K, Haranath PS. Influence of intragastric perfusion of aqueous spice extracts on acid secretion in anesthetized albino rats. Indian J Gastroenterol. 2000;19(2):53-6. 